\title{
Digitális munkarend vagy digitális oktatás? A karantén közoktatási tanulságai
}

A tanulási környezet változása, ezen belül a digitális oktatás szükségessége közel két évtizede témája az oktatással kapcsolatos szakmai és politikai párbeszédnek. A tárgyi fejlesztések ellenére a pedagógusok szakmai támogatása, továbbképzése elmaradt, és nem csak Magyarországon. A vizsgálatok az európai országok többségében a felkészültség hiányát jelzik. Jelen kutatás azt igyekezett feltárni, hogy - a koronavírus-járvány miatt bevezetett - digitális munkarend ideje alatt mennyiben valósult meg valóban digitális oktatás. Az eredmények azt mutatják, hogy a pedagógusok háromnegyede a Facebook-e-mail-Messenger hármasára támaszkodott a digitális munkarend idején, és inkább a hagyományos oktatást próbálta modellezni. Ugyanakkor a Google Classroom a digitális munkarend egyik nagy nyertese: a válaszadók közel 40 százaléka használta, egytizedük pedig ezt említette a legfontosabb, a hagyományos munkarendben is megőrzendő eredményként, ami pozitív hatással lehet a diákok eredményességére is.

Kulcsszavak: digitális oktatás, digitális írástudás, közoktatás, távoktatás, koronavírus-járvány

\section{Szerzői információ}

Kovács Edina, https://unideb.academia.edu/EdinaKovács

\section{Így hivatkozzon erre a cikkre:}

Kovács Edina. „Digitális munkarend vagy digitális oktatás? A karantén közoktatási tanulságai”. Információs Társadalom XXI, 3. szám (2021): 26-46. https://dx.doi.org/10.22503/inftars.XXI.2021.3.2

A folyóiratban közölt müvek

a Creative Commons Nevezd meg! - Ne add el! - Így add tovább! 4.0 Nemzetközi Licenc feltételeinek megfelelően használhatók. 


\section{Digital working arrangements or digital education? Con- clusions of quarantine in public education}

Changes of learning environment, especially the need for digital education have been important topic of professional and policy dialogue for nearly two decades. Despite the developments of equipment, the professional support and further training of teachers has been lacking, and not only in Hungary. Aim of this study is exploring how the digital working arrangements (due to the coronavirus epidemic) formed the education; was there digital education or not. The results show that three-quarters of teacher relied on the Facebook-e-mail-Messenger Triade during the digital working arrangements and tried to model traditional education. Google Classroom is one of the big winners of the digital working arrangements: it was used by nearly 40 percent of respondents, and a tenth of them mentioned it as the most important result to maintain in the traditional education.

Keywords: digital education, digital literacy, public education, blended learning, coronavirus epidemic 


\section{Bevezetés}

Az információs társadalom kialakulása az oktatásra is hatással van, két szempontból is: egyfelől az információs technológiák elterjedése hat az oktatásra, az alkalmazható módszerekre és tanulási módokra; másfelől az oktatásnak fel kell készítenie a felnövekvő generációt a technológia használatára, eligazodásra a technológia által vezérelt világban. Jelenleg azonban azt látjuk, hogy az információs technológia szerepe nagy az iskolán kívüli aktivitásokban, miközben az oktatás ezen a téren lemaradt (Burgeois, Birch és Davidovskaia 2019). Az, hogy az oktatási környezet még nem alkalmazkodott a digitális oktatáshoz, és úgy általában az atipikus oktatási formákhoz, nem magyar sajátosság: az OECD (2019) felmérése például azt mutatja, hogy az európai országok többségében a pedagógusok fele nem használja rendszeresen az IKT-eszközöket az oktatásban.

A koronavírus-járvány következtében ilyen körülmények között került sor az iskolákban a digitális munkarend bevezetésére. A válsághelyzet gyors alkalmazkodást kívánt; hogy ez mennyire volt sikeres, arról az elmúlt időszakban mindkét végletes értékelést hallhattuk. A digitális oktatás szempontjából azt érdemes vizsgálni, mennyiben sikerült ebben a távoktatási helyzetben az atipikus módszereket, különféle digitális alkalmazásokat igénybe venni, illetve mennyire próbálták - a megváltozott körülmények ellenére - a pedagógusok és az intézmények a hagyományos oktatást megvalósítani. Egy ilyen kutatás arra is rámutathat, melyek a leginkább fejlesztendő területek, mire lenne szükség ahhoz, hogy a digitális oktatás a köznevelés részévé váljon.

A továbbiakban áttekintjük, milyen feltételek megvalósulása esetén mondhatjuk, hogy egy adott oktatási folyamat valóban digitális. Ez ugyanis nemcsak az eszközöktől, hanem például a tanulásszervezés módjától, a tanár szerepétől, az információk forrásától is függ. Ezt követően arra keressük a választ, hogy a digitális munkarend ideje alatt mennyiben tudott a digitális oktatás valóban megvalósulni, továbbá hogy ahol ez akadályba ütközött, ott milyen tényezők jelentettek problémát. Első hipotézisünk, hogy a fiatalabb pedagógusok, akik már az Y generáció tagjai, nagyobb digitális jártasságuknak köszönhetően jobban meg tudták valósítani a ténylegesen digitális oktatást. A második hipotézis, hogy a sok hátrányos helyzetủ diákot oktató pedagógusok kevésbé tudtak digitális oktatást megvalósítani, elsősorban az eszközök és az elérhetőségek hiánya miatt. Harmadik hipotézisünk, hogy a kifejezetten jó helyzetű diákokat oktató pedagógusok, köszönhetően a jobb felszereltségnek és a diákok fejlettebb digitális írástudásának, inkább tudtak valóban digitálisan oktatni. A negyedik hipotézis pedig, hogy aki a digitális munkarend ideje alatt végül megismert megfelelő tanulástámogató alkalmazásokat, az ezeket a hagyományos oktatásba is nagyobb mértékben tervezi beilleszteni.

\section{Atipikus munkaformák és digitális írástudás}

Az atipikus módszerek az oktatásban nem újak: Kadocsa (2006) szerint itt említendők már a hetvenes évek reformpedagógiai mozgalmai is, amelyek Dewey, Freinet és Montessori elvei alapján a tapasztalati és a projektalapú tanulás fontosságára 
alapoztak. Ezek a nem hagyományos tanulási módokról szóló elgondolások az élethosszig tartó tanulás szükségességének megjelenésével és a technikai eszközök fejlődésével újra fontossá váltak. Az atipikus munkaformák közé tartozik a csoport- és teammunka, a peer learning, az egyéni módszerek közül a tapasztalati tanulás, az önálló tanulás, a gyakorlati tanulás, a nyitott tanulás, a távoktatás, a médiatanulás, a digitális tanulás és a blended learning. A távoktatás, ezen belül a digitális tanulás, és az e-learning olyan atipikus forma, amelynél alapvető a tanulás önirányítása, az oktató részéről csupán közvetett irányítás jelenik meg. A távoktatás előnye, hogy relatíve olcsó, költsége mintegy 30 százaléka a hagyományos osztálytermi tanulásnak. A távoktatás tananyagainak kifejlesztése ugyanakkor költségesebb a hagyományosnál.

Az új infokommunikációs eszközök megjelenése a hagyományos tanítás-tanulás szervezését, módszereit és tartalmát is át kellene, hogy alakítsa. Erre hívja fel a figyelmet Underwood (2009): a digitális technológia használata azt is igényelné, hogy ebből a szemszögből tekintsük át, hogyan tanulnak a tanulók, hogyan tanítanak a tanárok. A technológia alkalmazása ugyanis csak akkor tudja támogatni a hatékonyabb tanulást, ha megfelelő környezetben kerül rá sor.

A tanulási környezet változásai közül Kadocsa (2006) a következőket emeli ki: az információs társadalomban a tények és a kész megoldások tanítása helyett a készségek, kompetenciák kialakítására és fejlesztésére helyeződik a hangsúly, a tudás forrása pedig nem kizárólagosan az iskola és a tananyag - ehelyett a különböző forrásokból szerzett tudáselemek integrációjára kell törekedni. A hagyományos oktatás, illetve a távoktatás szemlélete között az egyik lényeges eltérés, hogy a tanárközpontúság helyett tanulóközpontúságra van szükség. Ugyanakkor továbbra is a tanár agya a legfontosabb hipermediális és szimulációs rendszer, amely a különféle anyagok (könyvek, szoftverek, feladatgyűjtemények, filmek, weblapok) és a tanulók között hoz létre - a fejlődéshez szükséges - kölcsönös megfeleléseket.

A tanulási környezet, a tanulás-tanítás folyamatának változása és az ehhez való alkalmazkodás a digitális oktatás egyik alapvető feltétele, a másik pedig az infokommunikációs eszközök használata, bevonása a tanulás folyamatába. A digitális írástudás (digital literacy) fogalma azonban jóval többet jelent, mint csupán az infokommunikációs eszközök ismerete, használatukra való képesség. Kárpáti (2013, 15) az UNESCO definícióját idézi: eszerint bármilyen írástudás „képesség arra, hogy megértsünk, interpretáljunk, megalkossunk, közöljünk és feldolgozzunk nyomtatott és egyéb módon közölt szövegeket, különböző közlési helyzetekben. Az írástudás folyamatos tanulást igényel, s így teszi lehetővé, hogy elérjük életcéljainkat, bővítsük ismereteinket és képességeinket, és hatékonyan vehessünk részt szűkebb és tágabb közösségünk életében.” Nelson, Courier és Gilbert (2011) szintén kiemelik a definíciók sokféleségét, majd ezt használják: a digitális írástudás az arra való képesség, hogy valaki értelmezni és használni tudja a számítógép közvetítésével többféle forrásból és formában érkező információkat. Burgeois, Birch és Davidovskaia (2019) az európai országok gyakorlatát tekintették át, és azt tapasztalták, hogy a digitális írástudás öt alapvető területe az egyes országokban használt definícióknak csupán körülbelül a felében jelenik meg. Az öt, általuk vizsgált terület: az információs és adatírástudás, a digitális tartalom létrehozására való képesség, kommunikáció és együttműködés képessége, digitális biztonság, valamint a problémamegoldás. Balázs (2020) szintén 
azt hangsúlyozza, hogy a digitális írástudás fejlesztésének célja, az IKT-eszközök tudatos alkalmazása mellett a kritikus gondolkodás fejlesztése is.

A diákokkal kapcsolatban két, egymásnak látszólag ellentmondó állítás fogalmazódik meg a szakirodalomban. Az egyik a Z generáció kapcsán azt hangsúlyozza, hogy ezek a diákok már beleszülettek az információs korba, számukra természetes a hálózati lét (Buda 2017). Hasonlóképpen fogalmaz Adesope és Rud (2019) is: úgy vélik, a diákok környezete ma már technológiai eszközökben gazdag, és ezek teljes mértékben integrálódnak az életükbe. Ennek kapcsán jelenti ki Balázs (2020), hogy a gyors információáramláshoz, egyszerre több feladattal való foglalkozáshoz (multitasking) szokott Z generáció diákjainak mások a tanulás szokásai is, mint az előző generációknak. Nekik már nem felel meg a kizárólag tankönyvalapú oktatás, hiszen általánosságban is több időt töltenek digitális játékokkal, és kevesebbet olvasással.

A másik állítás a diákok digitális oktatásra való felkészületlenségére vonatkozik. Kadocsa (2006) kiemeli: a digitális oktatás személyi feltétele tanulók részéről a digitális habitus megléte. Underwood (2009) szerint a digitális oktatás problémája egyben bármilyen tanítási módszer problémája is: az alulteljesítők többsége nincs felkészülve a tanulásra, nincsenek ehhez kellően fejlett gondolkodási, kognitív készségei. A látszólagos ellentmondást feloldja, ha tekintetbe vesszük, milyen hátrányok állhatnak a digitális járatlanság hátterében. Kertesi és Kézdi (2012) a roma diákok helyzetét vizsgálta, és arra a következtetésre jutott, hogy a roma tanulók szövegértés és matematika kompetenciamérésen tapasztalható lemaradása mögött társadalmi okok állnak. A szegregált lakókörnyezetben élő gyerekek ritkábban látnak például utcai feliratokat, rosszabb az ellátottságuk közkönyvtárakkal, és - ami témánk szempontjából fontos - a digitális kultúrához sem férnek hozzá. Az OECD (2015) átfogó kutatása pedig arra az eredményre jutott, hogy a nagy eltérések ma már nem pusztán a digitális eszközök meglétében, hanem azok minőségében jelennek meg. A legtöbb európai országban a diákok 90 százaléka hozzáfér valamilyen digitális eszközhöz otthon is; a helyzet Magyarországon is hasonló az az átlagoshoz, nálunk 87 százalékos volt ez az adat. Ugyanakkor jelentős a különbség a hozzáférés minőségében: az internet-hozzáférés például a legszegényebbek esetében az OECD átlagában 85 százalékos, Magyarországon 80 százalékos. A jelentés éppen Magyarországot és Lengyelországot említi példaként. Ezekben az országokban a kedvező szocioökonómiai státuszú diákok 84 százalékának otthonában két vagy több számítógép található, szemben a hátrányos helyzetűekkel, ahol az egész családra jut egy gép.

Ebből az aspektusból érthető a tanulók digitális írástudásában jelentkező eltérés, miközben minden tanulmány arra hívja fel a figyelmet, hogy ez a készség a technokrata, munkavállalói és fogyasztói képességek szempontjából is lényeges (Kárpáti 2013). Kővári (2019) hozzáteszi: amellett, hogy a digitális kompetencia a tanulás, a munkavégzés és a társadalmi szerepvállalás egyik mérföldköve, a csoportos feladatok a kooperatív készségeket is erősítik. Underwood (2009) is hangsúlyozza, hogy a digitális kompetenciák a társadalmi és a gazdasági részvétel szempontjából is szükségesek; ráadásul egyre több vizsgálat tudta mérhető módon kimutatni, hogy a tanulmányi eredményességre pozitív hatással van a digitális eszközök, technológiák alkalmazása. 
Molnár, Turcsányi-Szabó és Kárpáti (2020) azt járták körül, hogyan lehet a digitális eszközök segítségével a differenciált tanítást támogatni. Vizsgálták a mobileszközök, valamint a komoly játékok (serious games) alkalmazását. Azt állapították meg, hogy a mobileszközök segítik a tartalomhoz való hozzáférést, és az egymás közötti kommunikációt, így alkalmasak lennének a modern módszerek, például a kooperatív tanulás támogatására. Azonban az iskolákban ezeket többnyire házi feladatok készítésére, tesztek megoldására használták, ennél jobban nem aknázták ki a lehetőségeket. A komoly játékok esetében pedig arra hívták fel a figyelmet, hogy minél erősebb a fejlesztőanyag pedagógiai beágyazottsága, annál jobb hatást tud elérni a diákoknál. Konklúziójuk, hogy a jövő a személyre szabott intelligens rendszerek felé mutat. Így középfokon egyre nagyobb szerepet kaphat akár az önálló, tanár nélküli tanulás is, míg az alsóbb osztályokban a visszacsatoló rendszereknek lehet jelentősége, mivel ott a pedagógus személyes jelenléte is elengedhetetlen.

Az online és offline technológia vegyes alkalmazásának eredményességét vizsgálta Hua és Ren (2020). A tanár az online-offline oktatási környezetben feltölti a releváns forrásokat az online közegbe, értékelő modulokat alakít ki, és különféle interakciókat indít. A diákok pedig a feladatok teljesítésével szerezhetnek pontokat. A kutatók azt állapították meg, hogy a diákok jobb tanulmányi eredményt értek el ezzel a technológiával, emellett a tanár-diák kapcsolat is kielégítőbb volt, és a tanári elvárások is jobban teljesültek.

Balázs (2020) egy szakközépiskola diákjai esetében vizsgálta a Google Classroom alkalmazás hatékonyságát. Eredményei szerint a diákok 80 százaléka készíti el rendszeresen a Google Classroom alkalmazással kiadott házi feladatát, míg anélkül csak a diákok fele. A hagyományos rendszerben mindössze 19 százalékuk kap teljes mértékben visszajelzést a tanártól, míg Google Classroommal 43 százalékuk érzékelte ugyanezt. Arra a kérdésre, hogy rendelkezésre áll-e a tananyag, a Google Classroom segítségéve tanulók 72 százalék válaszolt igennel, míg a hagyományos rendszerben mindössze 41 százalékuk. Az összes eredmény értékelése azt mutatta, hogy a Google Classroom alkalmazásával egyértelműen rendszeresebb a tanulás. Ugyanez a kutatás azt is megállapította, hogy az otthoni tanulásnál a leggyakoribb eszköz a füzet (83 százalék), mivel a tanórákon azt használják. A második legnépszerübb az okostelefon (71 százalék), ezt az asztali számítógép és a laptop követi. A füzet szükségessége természetesen nagyban függ a pedagógus által használt eszközöktől és módszerektől - a továbbiakban az ezt meghatározó körülményeket tekintjük át.

\subsection{A pedagógusok és az intézmények digitális felkészültsége}

Az iskolák IKT-eszközökkel való felszereltsége, bár hagy még kívánni valót maga után, az elmúlt két évtized fejlesztési programjainak köszönhetően viszonylag jónak mondható Magyarországon. Az eredmények értelmezése - ahogyan erre Molnár és Pásztor-Kovács (2015) felhívja a figyelmet - attól is függ, hogy mi az, amit a pedagógus meg szeretne valósítani. Ha tudásszintmérő tesztet szeretne megoldatni átlagos méretű osztályával, akkor erre gond nélkül képes az általános iskolák 61 százalékában, a kettős funkciójú intézmények 73 százalékában, sőt a középiskolák 90 
százalékában az intézmény összes IKT-termét felhasználva. A középiskolák felében ugyanez még két osztállyal is végrehajtható, más intézményekben azonban ehhez már két időpontra lenne szükség.

Az IKT-lehetőségeivel tervező tanulási környezet kialakítása, vagy inkább annak hiánya, elsősorban tehát a pedagógusokon múlik. Az OECD első átfogó tanárkutatása, az első TALIS-vizsgálat során 2009-ben a megkérdezett tanárok negyede jelezte, hogy IKT terén továbbképzési igénye lenne, amelyre nem talál megoldást. Ez az OECD átlagában és Magyarországon is a három legfontosabb hiányterület egyike volt (Hermann et al. 2009). Az azóta zajló kutatások is azt tükrözik, hogy az oktatók nagy része nem rendelkezik kellő tudással és kellő idővel ahhoz, hogy megfelelő oktatási környezetet és programokat adaptáljon és/vagy hozzon létre. Dicheva és munkatársai (2015) szerint ez az oka annak, hogy például a gamifikált oktatás általában az informatikai kurzusokhoz kötődik. A felmérésben részt vevő országok felében a pedagógusok egy adott héten több időt fordítanak a tanításra, mint öt évvel ezelőtt, míg a felkészülésre szánt idő csökkent. Az OECD (2019) kutatása szintén azt mutatja, hogy az IKT-eszközök alkalmazásának gyakoriságát elsősorban a pedagógus ilyen jellegű képzettsége befolyásolja. A vizsgált országok átlagát tekintve a tanárok 53 százaléka ad rendszeresen IKT-eszközökkel megoldható feladatokat a diákjainak, míg 29 százalékuk alkalmanként.

Buda (2017) kutatása arra hívja fel a figyelmet, hogy a pedagógusok körében jelentős az elmélet és a gyakorlat eltérése. Ezt úgy kell érteni, hogy a vizsgálatba bevont pedagógusok válaszai négyfokú Likert-skálán 3,1 és 3,2 körüli átlagokat adtak a felkészültséggel, felszereltséggel kapcsolatos attitűdre vonatkozó kérdésekre. A tanórai alkalmazást illetően a tankönyv és a tábla-kréta után harmadik helyen áll a számítógép. Az interaktív tábla és a feleltető rendszer az eszközlista végére került. Az eredmények azt mutatják, hogy a tanárok nagy része nincs felkészítve a digitális eszközök használatára, bizonytalanok a tudásukat illetően.

Napjaink újabb kérdése - és egyelőre problémája - a tanárok szempontjából, hogy az IKT-használat a mobiltechnológiák felé tolódik, egyre nő a csoportos használat (például megosztás, kommentálás), és növekszik a multimediális tartalomfogyasztás (Kárpáti 2013), azaz már nem is a fent említett interaktív tábla lenne a legfontosabb oktatáshoz használt eszköz. Sung, Kuo-En és Tsu-Chien és (2016) ezzel a témával foglalkozó metaanalízisük során 110 tanulmányt tekintettek át. A legtöbb általuk elemzett kutatás arra hívta fel a figyelmet, hogy az alkalmazás legnagyobb akadálya, hogy a tanárok nem eléggé felkészültek. Kifejezetten fontos lenne a pedagógusok szakmai fejlesztése a mobil eszközök oktatási célú használatában. Arra kellene bátorítani őket, hogy szabják személyre a már létező oktatási alkalmazásokat, ahelyett hogy saját maguk próbáljanak létrehozni ilyen platformokat. Kooperatív tanulásra kevéssé használják a mobil eszközöket, még azok a pedagógusok sem élnek ezzel a lehetőséggel, akik visszajelzésre és feladatok kiadására igénybe veszik az IKT-eszközöket.

\section{A kutatás bemutatása: minta, módszerek, változók}

Kutatásunk során arra kerestük a választ, hogy a digitális munkarend ideje alatt mennyiben tudott valóban digitális oktatás megvalósulni, továbbá hogy ahol ez aka- 
dályba ütközött, ott milyen tényezők jelentettek problémát. Az első hipotézisünk az volt, hogy a fiatalabb (egyben kevesebb szakmai gyakorlattal rendelkező) pedagógusok, akik már az Y generáció tagjai, nagyobb digitális jártasságuknak köszönhetően jobban meg tudták valósítani a digitális oktatást. Második hipotézisként feltételeztük, hogy a sok hátrányos helyzetű diákot oktató pedagógusok kevésbé tudtak digitális oktatást megvalósítani, elsősorban az eszközök és az elérhetőségek (internet, szoftverek) hiánya miatt. A harmadik hipotézis, hogy a kifejezetten jó helyzetű diákokat oktató pedagógusoknak, köszönhetően a jobb felszereltségnek (nem elsősorban az iskolák, hanem a családok oldaláról) és a diákok fejlettebb digitális írástudásának, inkább volt lehetőségük valóban digitális oktatást véghez vinni. A negyedik hipotézisünk pedig az volt, hogy aki a digitális munkarend ideje alatt végül megismert megfelelő tanulástámogató alkalmazásokat, az ezeket a hagyományos oktatásba is nagyobb mértékben tervezi beilleszteni.

Az adatfelvétel 2020. június 6. és 15. között történt online megkereséssel. Mivel még ebben az időszakban is érvényben volt a digitális munkarend, és az iskolák csupán ügyeletet tartottak, más lehetőség nem is nyílt a pedagógusok elérésére. A kérdőívet szakmai fórumokon (levelezőlisták, Facebook) tettük közzé, és e-mailben is megkerestünk 200 iskolát, az ország egész területén. Az eredmények értékelésekor figyelembe kell venni, hogy emiatt a digitális kompetencia terén fejlettebb pedagógusok kerültek be a mintába; volt például a megkeresett intézmények között néhány, ahonnan visszapattant az e-mail, ami azt jelenti, hogy nem figyelik a fiókot, vagy nem jó cím szerepel az iskola honlapján. Ezen intézmények pedagógusai értelemszerűen nem kerültek be a mintába. Az így létrehozott DigIskola 2020 adatbázisa összesen 213 válaszadó adatait tartalmazza; bár a válaszadók, ahogy az alábbiakban látni fogjuk, nemek és korosztályok vonatkozásában is hasonló arányokkal rendelkeznek, mint a hazai pedagógustársadalom egésze, a mintavétel esetlegessége miatt az adatbázis semmilyen szempontból nem tekinthető reprezentatívnak. Arra ugyanakkor alkalmas, hogy egy esetleges nagymintás, reprezentatív kutatásig eltelő idő átértékelő, torzító vonásai nélkül kapjunk képet arról, hogyan zajlott az oktatás a digitális munkarend ideje alatt. Az elemzés során kereszttábla-elemzést, a korrelációk kimutatására faktoranalízist alkalmaztunk. Független változó volt az iskola településtípusa és a városrész/régió hátrányos vagy kedvező helyzete, a pedagógusok neme, a szakmai gyakorlati ideje, valamint az oktatás szint, amelyen tanítanak. A függő változók a digitális munkarendre és a digitális oktatásra, elsősorban az ezekkel kapcsolatos ismeretekre, gyakorlatra, képzésekre vonatkoztak.

\section{A kutatás eredményei}

Az eredmények sorában elsőként a válaszadó pedagógusok demográfiai jellemzőit, IKT-/digitális oktatáshoz kapcsolódó felkészültségét mutatjuk be. Ezt követően a digitális munkarend körülményit jellemezzük, majd a digitális munkarend során zajló oktatás módszertani sajátosságait, az információátadás és az értékelés megvalósulását és a pedagógusok által használt platformokat térképezzük fel. 


\subsection{Demográfiai jellemzők}

A válaszadók 74 százaléka nő, 22,7 százaléka férfi, 3,3 százalékuk nem kívánta megadni a nemét. Ez az arány megfelel a magyarországi pedagógustársadaloménak: a nők aránya az ország egészét tekintve 75 százalékos. ${ }^{1}$ Kutatásunkban a szakmai tapasztalat időtartamára kérdeztünk rá, azonban ha ennek alapján következtetünk az életkorra, a megoszlás szintén hasonló az országos átlagokhoz. ${ }^{2}$ Az életkor helyett azért választottuk a szakmai tapasztalatot változóként, mert lehetséges, hogy valaki más területen is dolgozott, és témánk szempontjából a szakmai tanulás lehetséges idejét éreztük inkább relevánsnak. A megoszlásokat az 1. ábrán mutatjuk be.

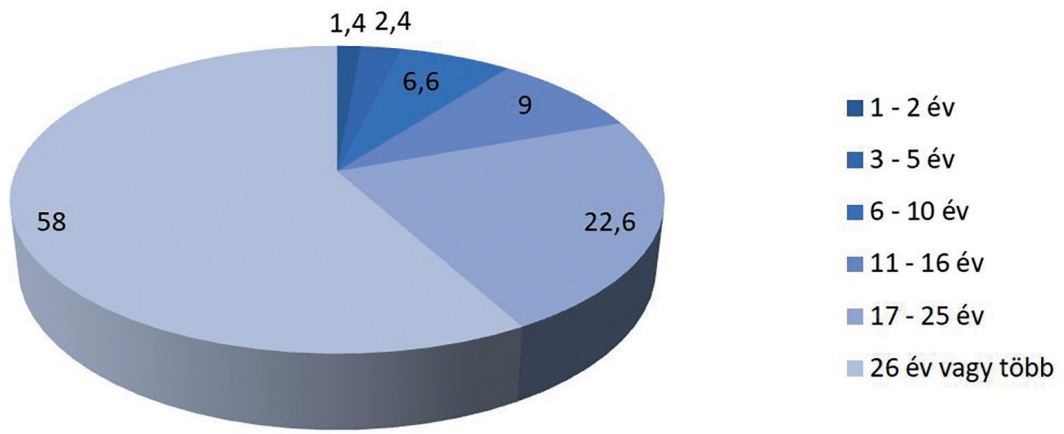

1. ábra: A szakmai tapasztalat alakulása a pedagógusok körében (\%)

(forrás: saját adatok)

A válaszadók 23 százaléka alsó tagozaton, 33 százaléka az általános iskola felső tagozatán, 44 százalékuk középiskolában tanít. Az intézmények fenntartója elsősorban az állam: 86,1 százalék dolgozik ilyen iskolában. 8,6 százalékos az egyházi iskolák aránya, a fennmaradó 5,3 százalék önkormányzati, alapítványi vagy más állami intézmény, például egyetem által fenntartott iskolában dolgozik. A válaszadó pedagógusok intézményének több mint fele nagyvárosban: megyeszékhelyen (26,5 százalék) vagy 10 ezer főnél nagyobb lélekszámú városban (32,2 százalék) található, a fővárosi iskolák aránya 9,5 százalék, 18 százalékos a kisvárosi, és 13,8 százalékos a falusi iskolák aránya a mintában. A megkérdezett pedagógusok több mint fele (52,4 százalék) átlagos gazdasági-társadalmi helyzetűnek (sem kiemelkedően jó, sem hátrányos) jellemezte az intézményében tanuló diákokat, 7,1 százalékuk kifejezetten hátrányos, 20,8 százalékuk inkább hátrányos helyzetünek, míg 13,2 százalék inkább jónak, 6,6 százalék pedig kifejezetten jónak ítélte ugyanezt.

Rákérdeztünk, hogy az elmúlt öt évben részt vettek-e a pedagógusok olyan, IKT-eszközökkel és digitális oktatással foglalkozó továbbképzésen, amelyet valóban hasznosíthatónak találtak. Utóbbi fontos kitétel, hiszen ahogy az elméleti áttekintésben láthattuk - például a Sung, Kuo-En és Tzu-Chien (2016) által írt tanulmányban -,

\footnotetext{
${ }^{1}$ Forrás: OECD Education at a Glance 2019

${ }^{2}$ Az OECD Education at a Glance 2019 adatai szerint a pedagógusok 5 százaléka 30 év alatti, 54 százalékuk 30-50 év közötti, és 41százalékuk 50 évesnél idősebb.
} 
a pedagógusoknak célzott támogatóképzésekre lenne szüksége. A megkérdezett pedagógusok fele kapott, a másik fele nem kapott támogatást ilyen továbbképzéshez, az arány minden háttértényező mentén hasonló. A saját intézmény vagy a fenntartó által szervezett képzésen a pedagógusok kétharmada vett részt; az arány szignifikánsan alacsonyabb a fóvárosban és magasabb a kisebb településeken. ${ }^{3}$ Autodidakta módon pedig a válaszadók 85 százaléka képezte magát. Azok, akik számára az elmúlt öt év során anyagilag (vagy munkaidő-kedvezménnyel) nem támogatták a továbbképzési részvételét, saját szervezésű képzésen 34 százalékban tudtak részt venni, míg kétharmaduk nem kapott ilyen lehetőséget. A két változó együttes vizsgálatából az következik, hogy a pedagógusok egyharmada semmilyen digitális oktatáshoz kapcsolódó képzésben nem részesült az elmúlt öt év folyamán. Ehhez képest saját IKT-/digitális felkészültségét a válaszadók 57,6 százaléka értékelte nagyon jónak, további 20,5 százaléka inkább jónak. A háttérváltozók tekintetében kizárólag az iskola településtípusával volt kimutatható az összefüggés: a fővárosi iskolákban csak a pedagógusok 30 százaléka értékelte magát nagyon felkészültnek, ugyanez az arány a megyeszékhelyeken és a nagyvárosokban kétharmadnyi volt, míg a kisebb városokban és a falvakban a pedagógusok fele ítélte nagyon felkészültnek önmagát. ${ }^{4}$

\subsection{A digitális munkarend körülményei}

\begin{tabular}{|l|l|l|l|l|l|l|}
\hline & $\begin{array}{c}\text { Kifejezetten } \\
\text { hátrányos }\end{array}$ & $\begin{array}{c}\text { Inkább } \\
\text { hátrányos }\end{array}$ & Átlagos & $\begin{array}{c}\text { Inkább } \\
\text { jó }\end{array}$ & $\begin{array}{c}\text { Kifejezetten } \\
\text { jó }\end{array}$ & Össz. \\
\hline $\begin{array}{l}\text { Lényegében } \\
\text { mindenkit }\end{array}$ & $\mathbf{2 0}$ & 43,2 & 61,3 & 67,9 & $\mathbf{7 8 , 6}$ & 56,6 \\
\hline 90 százalékot & 0 & 25 & 15,3 & 21,4 & 0 & 16 \\
\hline $\begin{array}{l}80-89 \\
\text { százalékot }\end{array}$ & $\mathbf{2 6 , 7}$ & 13,6 & 11,7 & 7,1 & 14,3 & 12,7 \\
\hline $\begin{array}{l}\text { 66-79 } \\
\text { százalékot }\end{array}$ & 20 & 11,4 & 9 & 3,6 & 7,1 & 9,4 \\
\hline A diákok felét & $\mathbf{1 3 , 3}$ & 4,5 & 2,7 & $\mathbf{0}$ & $\mathbf{0}$ & 3,4 \\
\hline $\begin{array}{l}\text { A diákok egy- } \\
\text { harmadát }\end{array}$ & $\mathbf{1 3 , 3}$ & 2,3 & 0 & $\mathbf{0}$ & $\mathbf{0}$ & 1,4 \\
\hline Szinte senkit & $\mathbf{6 , 7}$ & 0 & 0 & $\mathbf{0}$ & $\mathbf{0}$ & 0,5 \\
\hline
\end{tabular}

1. táblázat: A hátrányos helyzet és a diákok elérésének összefüggése (\%) (forrás: saját adatok. Khí-négyzet próba, p=0,000)

A digitális munkarend bevezetéséről a megkérdezett pedagógusok többsége (63,7 százalék) március 13-án pénteken este értesült. 27,8 százalékuk a hétvége során, 6,1

\footnotetext{
$\overline{\text { khí-négyzet próba, }} \mathrm{p}=0,005$

${ }^{4}$ khí-négyzet próba, $\mathrm{p}=0,026$
} 
százalékuk március 16-án hétfőn, és 2,4 százalékuk (ez összesen 5 főt jelent) még ennél is később. A diákokat a kérdezettek több mint fele (56,8 százalék) teljes mértékben elérte, további 16 százalék is úgy válaszolt, hogy jellemzően a diákok 90 százalékát elérte digitális eszközökkel. Az elérést illetően településtípus szerint nincsen szignifikáns különbség, és aszerint sem, hogy a pedagógus milyen oktatási szinten tanít. Meghatározó ugyanakkor a társadalmi-gazdasági helyzet: a kifejezetten jó helyzetű diákokat tanítók közel 80 százaléka, míg a kifejezetten hátrányos helyzetűeket tanítók 20 százaléka tudott mindenkit elérni (az adatokat részletesen az 1. táblázat mutatja be).

Arra is rákérdeztünk, hogy aki nem érte el a diákok egy részét, hogyan tudta kezelni ezt a helyzetet. A szöveges válaszokból kiderül, hogy az elérés hiánya mögött többféle ok is meghúzódott. Néhány esetben a gyermekek életkora okozott gondot (alsó tagozat, első-második osztály), amikor a szülővel való kapcsolatfelvétel segített. A szöveges válaszok körülbelül tíz százalékában azt jelezték, hogy nem az eszközök hiánya, hanem az értékelés szándékos elkerülése állt az elérhetetlenség mögött; ez az érintett tanárból frusztrációt és ellenállást váltott ki. A hátrányosabb helyzetű települések esetében viszont inkább az eszközök, esetleg a szülői jelenlét hiánya okozta, hogy nem érték el a tanulókat. A megoldások sorában tipikusnak mondható a következő válasz: „Hetente feladatlapokat állítottam össze, amiket az iskola kinyomtatva kiküldött a tanulóknak. Miután a tanulók visszaküldték, az osztályfőnökök beszkennelve átküldték nekem, és kijavítottam, leosztályoztam”.

Valószínűsíthető, hogy a digitális munkarend a pedagógusok egy részét szülőként is érintette, így feltételeztük, hogy ők az otthoni eszközeiket használták, hiszen így tudták megoldani, hogy egyszerre tudjanak tanítani és a saját gyermekeikre is vigyázni. Összesen a pedagógusok 11 százaléka mondta, hogy praktikus indok miatt használta a saját, otthoni számítógépét és internetelérését. A válaszadók 46 százaléka viszont azért kényszerült a saját eszközeit és még inkább internetelőfizetését használni, mert sem a fenntartó, sem a saját intézmény nem tudta ezeket biztosítani számára. A többiek főként számítógépet vagy laptopot kaptak, de a pedagógusok 5 százaléka számára is a fenntartó/intézmény biztosított eszközt és internetet. Olyan nem volt, aki az eszközök hiánya miatt egyáltalán nem tudott digitális csatornákon tanítani ebben az időszakban. A válaszadók közel felének nem írták elő központilag valamilyen platform használatát, és bár a sajtóhírek szerint a szülők számára ez nem feltétlenül volt pozitív, a digitális oktatás szempontjait figyelembe véve valószínűsíthető, hogy ez volt a kedvezőbb megoldás. Főként, ha azt is hozzátesszük, hogy a megkérdezett pedagógusok több mint egyharmadának előírták az egységes felületet/platformot, ők azonban emellett mást is igénybe vettek. Mindössze 13,3 százalék volt, akinek előírták, mit kell használnia, és kizárólag ezt használta. Mivel a mintába került intézmények többsége állami fenntartású, a különféle verziók (volt előírt platform, vagy sem, azt használták-e ténylegesen, vagy sem) közöttük oszlanak meg, eközben elmondható, hogy az egyházi intézmények ebben a tekintetben szabad kezet adtak a pedagógusoknak. A település vagy a régió gazdasági helyzete szempontjából ebben a kérdéskörben nem mutatható ki szignifikáns eltérés.

Az órarendhez való igazodást illetően nagyon megoszlanak az előírások és a lehetőségek is. A pedagógusok 22,5 százalékának előírták, hogy az órarendet megtart- 
va tanítsanak, míg 21,1 százalékuk esetében nem volt ilyen előírás, mégis igyekeztek az órarendet tartani. 22,1 százalékuk számára ugyan volt előírás, de a valóságban igyekeztek ennél rugalmasabban tartani a kapcsolatot a diákokkal, 34,3 százalékuk pedig szintén rugalmasan, nem a hagyományos órákat modellezve tanított, és nem volt számukra előírás, hogy az órarendhez igazodjanak. A rugalmasság-rugalmatlanság dimenziójában két háttérváltozó mentén is láthatunk szignifikáns eltéréseket. Az alsó tagozaton és a középiskolákban tanítók rugalmasabban kezelték az órák megtartását, míg a felső tagozaton dolgozók inkább követték az órarendet. A kedvezőbb, illetve a hátrányosabb helyzetű iskolák között még jelentősebb az eltérés, ezt a 2. táblázatban mutatjuk be. Ahogy látható, a kifejezetten jó helyzetű városrészben, régióban működő iskolák esetében a pedagógusok közel háromnegyede az órarendnél rugalmasabb tananyag-feldolgozást valósított meg (többségük számára nem is volt előírás, hogy tartsa magát az órarendhez). Ugyanakkor a kifejezetten hátrányos helyzetű városrészben, régióban működő intézmények 60 százalékában az órarendet kellett követni, és ezt csak a pedagógusok 20 százaléka kezelte az elöírtnál rugalmasabban. A szakmai tapasztalat szempontjából viszont nem volt eltérés a pedagógusok között.

\begin{tabular}{|l|l|l|l|l|l|l|}
\hline & $\begin{array}{c}\text { Kifejezetten } \\
\text { hátrányos }\end{array}$ & $\begin{array}{c}\text { Inkább } \\
\text { hátrányos }\end{array}$ & Átlagos & $\begin{array}{c}\text { Inkább } \\
\text { jó }\end{array}$ & $\begin{array}{c}\text { Kifejezetten } \\
\text { jó }\end{array}$ & Össz. \\
\hline $\begin{array}{l}\text { Előírták, és így } \\
\text { tartottam }\end{array}$ & $\mathbf{4 0}$ & $\mathbf{9 , 1}$ & 25,2 & 28,6 & $\mathbf{7 , 1}$ & 22,5 \\
\hline $\begin{array}{l}\text { Előírták, de } \\
\text { eltértem }\end{array}$ & 20 & 20,4 & 27 & $\mathbf{1 0 , 7}$ & $\mathbf{1 4 , 3}$ & 22,1 \\
\hline $\begin{array}{l}\text { Nem volt } \\
\text { elóírás, de } \\
\text { tartottam }\end{array}$ & 6,7 & $\mathbf{3 4 , 1}$ & 19,8 & 14,3 & 21,4 & 21,1 \\
\hline $\begin{array}{l}\text { Nem volt } \\
\text { elóírás, és ru- } \\
\text { galmasabban } \\
\text { tartottam }\end{array}$ & 33,3 & $\mathbf{3 6 , 4}$ & 27,9 & $\mathbf{4 6 , 4}$ & $\mathbf{5 7 , 2}$ & 34,3 \\
\hline
\end{tabular}

2. táblázat: A hátrányos helyzet és az órarend szerinti oktatás összefüggése (\%)

(forrás: saját adatok. Khí-négyzet próba, p=0,042)

\subsection{A digitális munkarend módszertana, a tanítás megvalósítása}

Rákérdeztünk, hogyan alakult a pedagógusok felkészülésre és oktatásra fordított ideje a digitális munkarend bevezetését követően. Az várható volt, hogy az időszak elején több időt kellett oktatással, ezen belül főleg felkészüléssel tölteni, hiszen nem állt rendelkezésre azonnal használható digitális tananyag, ahogyan kidolgozott feladatok és már bejáratott applikációk sem. A megkérdezett pedagógusoknak azonban csak 17 százaléka választotta ezt a válaszlehetőséget. Több mint 60 százalékuk úgy ítélte meg, hogy végig jóval nagyobb erőfeszítéseket tett, mint korábban, és további 
14,1 százalék valamivel nagyobbnak ítélte az időráfordítást. A 2. ábráról leolvasható az is, hogy a 3 százalékot sem éri el azok aránya, akik a hagyományos oktatáshoz képest kevesebb időt fordítottak a digitális munkarend alatti tanításra.

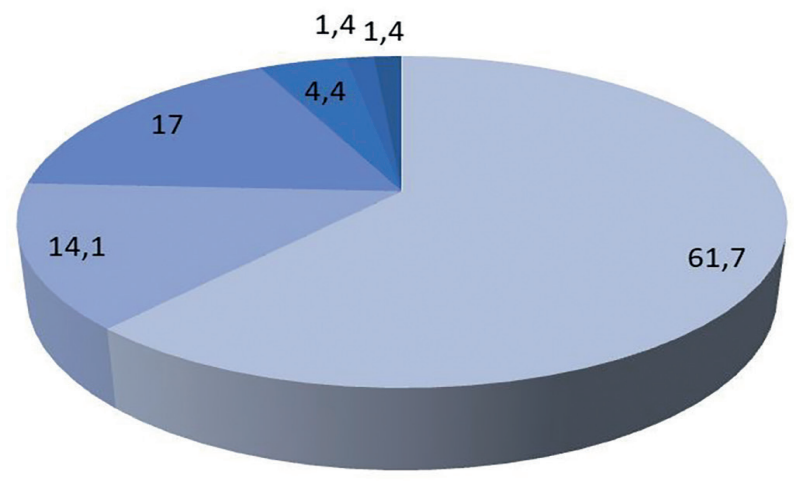

\author{
Sokkal többet \\ - Valamivel többet \\ Az elején többet, utána \\ ugyanannyit \\ Körülbelül ugyanannyit \\ Valamivel kevesebbet \\ Sokkal kevesebbet
}

2. ábra: A felkészülésre/oktatásra fordított idő, a korábbi időszakhoz képest (\%) (forrás: saját adatok)

Az időráfordításban sem a fenntartó, sem a településtípus, sem nemek szerint nem mutatható ki szignifikáns eltérés. Látható viszont összefüggés a hátrányos helyzet és az oktatásra fordított idő között: a kifejezetten jó helyzetű intézmények pedagógusainak 57 százaléka fordított sokkal több, vagy valamivel több időt a tanításra a digitális munkarend alatt, míg ugyanez az arány a kifejezetten hátrányos helyzetű intézményeinek pedagógusainál 85,7 százalék. ${ }^{5}$ A szakmai gyakorlat pedig még ennél is erőteljesebben hatott a felkészüléssel és oktatással töltött időre: a tízévnyi vagy annál kevesebb szakmai gyakorlattal rendelkező, azaz a huszonéves, legfeljebb a harmincas éveik elején járó pedagógusoknak csak valamivel több mint a fele fordított több időt az oktatásra, mint a hagyományos munkarend idején; ugyanez az arány a 26 évnyi vagy annál több szakmai gyakorlattal rendelkező tanárok esetében 79 százalék. A hagyományos munkarendnél kevesebb időt pedig kizárólag a fiatalabb korosztályok töltöttek tanítással a digitális munkarend ideje alatt (3. táblázat).

\begin{tabular}{|l|l|l|l|l|}
\hline & \multicolumn{1}{|c|}{$\begin{array}{c}\text { 10 év vagy } \\
\text { kevesebb }\end{array}$} & $\begin{array}{c}11-25 \text { év kö- } \\
\text { zött }\end{array}$ & 26 év vagy több & Összesen \\
\hline $\begin{array}{l}\text { Sokkal több } \\
\text { időt }\end{array}$ & 45,5 & 56,9 & 67,2 & 61,7 \\
\hline $\begin{array}{l}\text { Valamivel több } \\
\text { időt }\end{array}$ & 9,1 & 20 & 11,8 & 14,1 \\
\hline $\begin{array}{l}\text { Eleinte több } \\
\text { időt, aztán ua. }\end{array}$ & 18,2 & 13,8 & 18,5 & 17 \\
\hline
\end{tabular}

\footnotetext{
$\overline{{ }^{5} \text { khí-négyzet próba, }} \mathrm{p}=0,028$
} 


\begin{tabular}{|l|l|l|l|l|}
\hline $\begin{array}{l}\text { Ugyanannyi } \\
\text { időt }\end{array}$ & 4,5 & 7,8 & 2,5 & 4,4 \\
\hline $\begin{array}{l}\text { Valamivel } \\
\text { kevesebb idő }\end{array}$ & $\mathbf{1 3 , 6}$ & 0 & $\mathbf{0}$ & 1,4 \\
\hline $\begin{array}{l}\text { Sokkal keve- } \\
\text { sebb időt }\end{array}$ & $\mathbf{9 , 1}$ & 1,5 & $\mathbf{0}$ & 1,4 \\
\hline
\end{tabular}

3. táblázat: Az oktatásra fordított idő és a szakmai gyakorlat összefüggése (\%) (forrás: saját adatok. Khí-négyzet próba, p=0,000)

Rákérdeztünk, hogy a pedagógusok mennyire ismertek bizonyos oktatási célú alkalmazásokat a digitális munkarend bevezetése előtt. A ClassCraft és a ClassTools a válaszadók több mint 90 százaléka számára volt ismeretlen, az Okosdoboz és Redmenta valamivel több mint 40 százalékuknak, a Moodle, a GoogleTeams és a Zoom háromnegyedüknek, míg a Microsoft Classroom 56,3 százalékuknak. A Facebook és a Skype esetében fordulnak az arányok: ezeket a válaszadók több mint 80 százaléka ismerte. Talán meglepő lehet, de nincs szignifikáns összefüggés az alkalmazások ismerete és a szakmai gyakorlat/életkor között, egyedül a Skype volt valamivel ismertebb a fiatalabbak esetében. Az egyéb háttérváltozókkal pedig kizárólag az OkosDoboz mutat szignifikáns összefüggést: a nők fele, míg a férfiaknak csupán a negyede ismerte ezt az alkalmazást már a digitális munkarend bevezetése előtt, ${ }^{6}$ a hátrányos helyzetű városrészekben található iskolák pedagógusainak pedig a háromnegyede, szemben a kifejezetten jó helyzetű intézményekkel, ahol csak a pedagógusok negyede mondta ugyanezt. ${ }^{7}$

Ezt követően megkérdeztük, hogy a fenti alkalmazások közül melyiket használták leggyakrabban a digitális munkarend ideje alatt, továbbá a második és a harmadik leggyakoribb alkalmazásra is. A három említési lehetőségnél felmerülő alkalmazások gyakorisági sorrendje így alakult:

$\begin{array}{lr}\text { Facebook } & 137 \\ \text { Google Classroom } & 87 \\ \text { Redmenta } & 63 \\ \text { Zoom } & 59 \\ \text { OkosDoboz } & 53 \\ \text { Skype } & 41 \\ \text { Google Teams } & 32 \\ \text { Moodle } & 11\end{array}$

Az egyéb használt alkalmazások sorát a Kréta vezeti 35 említéssel, a második leggyakoribb az e-mail (18) és a LearningApps (18). Gyakori még a Wordwall (16), a Messenger (15) és a YouTube (13) is. Az eredményekből az is kiderül, hogy a Facebookot, az e-mailt és a Messengert használták elsősorban a pedagógusok: ezek az alkalmazások nem nevezhetők oktatási felületnek (és az e-mailt, mivel nem digitá- 
lis platform, vélhetően a válaszadók egy része nem is tekintette annak; ez lehet az oka, hogy viszonylag alacsony az említések száma). A Kréta, bár sok helyen kötelező volt, az említések számából ítélve nem tett szert nagy népszerűségre, míg a Google Classroom és a Redmenta többeknél jól bevált: összesen a válaszadók közel háromnegyede említette ezeket. Nyilván voltak olyanok, akik mindkettőt használták, így a valóságban ez az arány inkább kétharmad körül alakul, de még így is jó beválásnak értelmezhető.

Két kérdésblokkban vizsgáltuk, hogy milyen módszereket választottak a pedagógusok az ismeretátadásra, illetve az értékelésre. Mindkét blokk esetében hatfokú Likert-skálán jelölhették meg a gyakoriságot a válaszadók. Az ismeretátadási módszerek között az „online óra”, a „videós magyarázat”, a „hangfájl magyarázat”, „diavetítés (például PowerPoint)”, az „írásos magyarázat”, a „kiadott anyag önálló feldolgoztatása”, valamint a „projektfeladat” szerepelt. Az értékelés blokkjában az „önjavító feladat”, a „digitális platformon megoldandó feladat”, az „online feleltetés”, a „digitálisan készített feladat/dolgozat”, a „papíron készített feladat/dolgozat”, a „tanuló által készített kép vagy videó” és a „tanuló által készített hangfájl” válaszok jelentek meg. Az ismeretátadás blokkjánál lehetőséget adtunk az „egyéb” módszer megnevezésére is. Az erre válaszolók leggyakrabban (23 esetben) az oktatóvideót jelölték meg, ezt valamiért nem érezték azonosnak a „videós magyarázat” válaszlehetőséggel; noha olyan is volt a 23 válaszadók között, aki saját anyagot készített, ami lényegében a videós magyarázat legszűkebb definíciója. Sajátos, hogy 15 alkalommal tesztek, feladatok kiadását nevezték meg itt: ez arra utal, hogy a válaszadó a számonkérést-értékelést tekintette ismeretátadásnak.

$\mathrm{Az}$ ismeretátadási módszerek sorában a leggyakoribb az „Írásos magyarázat, beszkennelve, e-mailben stb.” használata volt (átlag 4,5), a második leggyakoribb a kiadott anyag önálló feldolgoztatása (átlag 3,9), és az inkább használt kategóriába került a diavetítéses magyarázat is, míg a többi átlag az inkább nem, vagy a ritkán használt értéket jelöli. Az értékelési módszerek között a leggyakrabban használt a digitális platformon megoldott, pedagógus által értékelt feladat (átlag 4,2), és az inkább használt kategóriába került, egyformán 3,7 átlaggal a digitálisan készített dolgozat/feladatlap, a papíron készített dolgozat/feladatlap és a tanuló által elkészített kép vagy videó; a többi átlag itt is az inkább nem kategóriát jelenti.

A választott ismeretátadási és értékelési módok közötti korrelációt faktorelemzés segítségével vizsgáltuk. Bár az összefüggés nem erős, az egyes faktorokban a háttérváltozók mentén mutatkozó szignifikáns eltérések felhívják a figyelmet néhány fontos jelenségre, így érdemes ezeket megnéznünk, természetesen szem előtt tartva a csekélyebb magyarázó erőt. A változókból főkomponens-elemzéssel öt faktort lehetett létrehozni, ezeket a 4. táblázat mutatja be.

Az egyes és a kettes faktorba rendeződtek a valóban digitális oktatási módszerek; az első inkább a diákok munkájára, a második inkább az ismeretek közlésére helyezi a hangsúlyt. A harmadik faktor a hagyományos oktatás szimulációja: online eszközökkel megtartott órákat és feleltetést foglal magában. A negyedik faktorban a tanulói teljesítményt hangsúlyozó mutatók vannak, míg az ötödik faktor a papíralapú megoldást tartalmazza (ebben viszonylag erős, bár 0,5 alatti faktorsúllyal jelenik meg az írásos magyarázat is). 


\begin{tabular}{|l|r|r|r|r|r|}
\hline & $\begin{array}{c}\text { Digitális } \\
\text { munkáltató }\end{array}$ & $\begin{array}{c}\text { Digitális } \\
\text { közvetító }\end{array}$ & $\begin{array}{c}\text { Hagyo- } \\
\text { mányos } \\
\text { oktató }\end{array}$ & $\begin{array}{c}\text { Munkál- } \\
\text { tató }\end{array}$ & Papíralapú \\
\hline Projektfeladat &, 676 &, 033 &, 137 &, 246 &,- 316 \\
\hline $\begin{array}{l}\text { Önálló feldolgoz- } \\
\text { tatás }\end{array}$ &, 661 &, 016 &,- 139 &, 084 &, 047 \\
\hline Digitális dolgozat &, 594 &, 024 &, 411 &,- 248 &, 219 \\
\hline Írásos magyarázat &, 436 &, 066 &,- 216 &, 284 &, 416 \\
\hline Diavetítés &, 060 &, 681 &, 171 &, 132 &, 057 \\
\hline Videós magyarázat &,- 256 &, 673 &, 013 &, 243 &,- 069 \\
\hline Önjavító feladat &, 153 &, 640 &,- 063 &,- 146 &,- 022 \\
\hline Online óra &,- 109 &, 058 &, 776 &,- 059 &,- 127 \\
\hline Online feleltetés &, 092 &, 070 &, 749 &, 279 &,- 012 \\
\hline $\begin{array}{l}\text { Tanuló által készí- } \\
\text { tett kép }\end{array}$ &, 123 &,- 068 &, 017 &, 725 &, 219 \\
\hline Hangfájl &,- 089 &, 211 &, 141 &, 657 &, 022 \\
\hline Papíralapú dolgozat &,- 079 &,- 070 &,- 110 &, 229 &, 771 \\
\hline $\begin{array}{l}\text { Digitális, javítandó } \\
\text { feladat }\end{array}$ &, 448 &,- 266 &,- 392 &, 490 \\
\hline
\end{tabular}

4. táblázat: A digitális munkarend alatt használt ismeretátadó és értékelési módszerek (faktorszkórok)

(forrás: saját adatok. Varimax, $\mathrm{KMO}=0,609$ )

A faktorok az oktatási szintek, valamint a hátrányosabb/jobb helyzetben levő városrészek szerint mutattak szignifikáns eltérést. A szakmai gyakorlat időtartama nem volt hatással a változók közötti összefüggésre. Az oktatási szintek szerint a középiskolai tanárok felülreprezentáltak az 1. és a 3. faktorban, ${ }^{8}$ az általános iskola felső tagozatán tanítók az 5. faktorban, ${ }^{9}$ míg az alsó tagozaton tanítók a 4. faktorban, ${ }^{10}$ A település, városrész társadalmi-gazdasági helyzete alapján a kifejezetten jó és az inkább jó helyzetű intézmények pedagógusai felülreprezentáltak az 1 . faktorban, ${ }^{11}$ a kifejezetten jó helyzetűek a 3. faktorban is. ${ }^{12}$ A kifejezetten hátrányos helyzetű intézmények pedagógusai pedig a 4 . faktorban. ${ }^{13}$ Mivel az 5. faktorban tendenciaszerúen

\footnotetext{
${ }_{9}^{8} \mathrm{p}=0,000$

${ }_{9} \mathrm{p}=0,020$

${ }^{10} \mathrm{p}=0,000$

${ }_{11}^{11} \mathrm{p}=0,017$

${ }_{12} \mathrm{p}=0,000$

${ }^{13} \mathrm{p}=0,028$
} 
felülreprezentáltak volt a kifejezetten hátrányos helyzetű intézmények, kereszttábla-elemzéssel néztük meg, hogy a papíralapú dolgozatokkal történő értékelésben látható-e szignifikáns eltérés e háttérváltozó mentén. A kifejezetten hátrányos helyzetű intézmények tanárainak 60 százaléka használta nagyon gyakran vagy gyakran ezt az értékelési módot, szemben a kifejezetten jó helyzetű intézmények pedagógusaival: itt 14,2 százalékos ugyanez az arány. ${ }^{14}$

A kérdőív végén lehetőséget adtunk arra, hogy a válaszadók röviden értékeljék a digitális munkarendet, ezen belül a leginkább megterhelő mozzanatot, valamint a szakmai szempontból megtartandó eredményeket. A 213 pedagógus háromnegyede, 166 fő élt ezzel a lehetőséggel. A nehézségek között leggyakrabban (17 esetben) említik a rossz munkakörülményeket: sokat kellett a gép előtt ülni, a monitort nézni, ami fizikailag is megterhelő volt. Nagy arányban nevezték meg a munkaidő teljes felborulását (12 esetben), azt, hogy a kapcsolattartás, felkészülés, javítás a hétvégékbe vagy az éjszakákba is belenyúlt. Ugyanennyien említik, hogy nehéz volt az értékelés, a feladok begyüjtése, és - amennyiben azok szkennelve érkeztek - a konkrét értékelés is. Hatan említik, hogy nehéz volt közben a saját gyermekeiket is ellátni, ugyanennyien a személyes jelenlét hiányát teszik szóvá. A felkészülés hiányát, azt, hogy nem volt idő az átállásra, valamilyen formában 14 válaszadó fogalmazta meg. Jól tükrözi a véleményeket a következő válasz: „Amiket most ingyenessé tettek, sajnos csak most ismertem meg, pedig már profin kellene használnom”. A dupla adminisztrációt (Kréta, papíralapú napló, különböző felületek kitöltése) hét esetben említették meg. Az IKT-eszközök hiányát 11 válaszadó jelezte, részben a diákok oldaláról, részben a saját eszköz tekintetében. A tananyaggal kapcsolatos problémákat többen is megfogalmaztak, összességében 30 említés található a válaszok között, ezek azonban, valamelyest eltérő módón, három főbb területre helyezik a hangsúlyt. Az első a digitális tananyagok hiánya, a második, hogy a saját készítésű anyagok nem álltak rendelkezésre, míg a harmadik a keretrendszerre vonatkozik inkább: ez a tananyag nem alkalmas a digitális oktatásra a válaszadók szerint.

Az előnyök között 45 alkalommal említik meg a digitális tananyagok megismerését, a digitális kompetenciák fejlődését. A legtöbben hozzáteszik, hogy mindenképp szükségesnek tartják a hagyományos oktatást - ami érthető: a pedagógus facilitátori jelenléte, a konzultáció lehetősége még a klasszikus definíciók szerint is szükséges -, ugyanakkor a csoportmunkát vagy a differenciálást támogató platformokat gyakrabban fogják használni. A konkrét említések között a Google Classroom a leggyakoribb (17 esetben), a Redmenta a második (6 esetben). A legjobban talán a következő idézet foglalja össze ezeket a válaszokat: „Rengeteg felületet megismertem, beleástam magam. A mozaBook nagyszerüségét eddig is ismertem, de most úgy érzem nagy hiba, hogy nem kötelező akár. Mindenkinek ismernie kellene! Szívesen használnám ezeket. Kellene sok eszköz a suliba! Áldoznia kéne rá a kormánynak!” A válaszadók a fentiek mellett néhány alkalommal a PowerPoint és a Prezi használatát, ezekből alámondásos videó készítését, és összességében a rugalmasságot is a megőrzendő pozitívumok között említették. .

\footnotetext{
$\overline{{ }^{14} \text { khí-négyzet próba, }} \mathrm{p}=0,010$
} 


\section{4. Összegzés}

Kutatásunkban azt vizsgáltuk, hogy a koronavírus-járvány alatt, a köznevelési intézményekben bevezetett digitális munkarend hogyan hatott a tanítási folyamatra; mennyiben tudott valóban digitális oktatás kialakulni. Az első hipotézis úgy szólt, hogy az Y generációhoz tartozó, egyben kevesebb szakmai gyakorlattal rendelkező pedagógusok nagyobb digitális jártasságuknak köszönhetően jobban meg tudták valósítani a digitális oktatást. Ez a hipotézis nem igazolódott be: az oktatáshoz használható szoftverek, alkalmazások ismeretét illetően nem volt eltérés a pedagógusok között a szakmai tapasztalat mentén. Nem voltak felülreprezentáltak a fiatalabbak a két digitális módszereket tartalmazó faktorban sem. Egyetlen függő változó mutatott eltérést a szakmai gyakorlat ideje szerint: a fiatalabbak körében szignifikánsan kevesebben töltöttek sokkal több időt a felkészüléssel és a tanítással a hagyományos oktatásra fordított időhöz képest. Ezt az eredményt azonban óvatosan kell értékelnünk, épp azért, mert nem társulnak hozzá más változókban mutatkozó eltérések. A háttérben állhat ugyan az Y generáció fejlettebb digitális kompetenciája, és az, hogy ennek köszönhetően kellett kevesebbet készülniük, mint az idősebbeknek; de az is előfordulhat, hogy - épp a rutin hiánya miatt - ők a hagyományos oktatás során tartott óráikra is többet készülnek, mert egyelőre kevesebb kidolgozott óratervük, feladatlapjuk, PPT-jük gyült össze, mint a 25 évnél hosszabb ideje pályán levőknek.

Második hipotézisünk, hogy a sok hátrányos helyzetủ diákot oktató pedagógusok kevésbé tudtak digitális oktatást megvalósítani, elsősorban az eszközök és az elérhetőségek (internet, szoftverek) hiánya miatt. Ez a hipotézis igazolódott: a hátrányos helyzetủ városrészekben, iskolákban dolgozó pedagógusoknak csak 46,7 százaléka mondta, hogy legalább a diákok 80 százalékát el tudta érni, a többiek értelemszerűen igyekeztek papíralapon tanári magyarázatot és feladatokat küldeni a tanulóknak. Valószínüleg ez magyarázza, hogy az oktatásra 85,7 százalékuk fordított több, vagy sokkal több időt, mint a hagyományos munkarend alatt. Hogy az eltérések elsősorban valóban az iskola diákjainak társadalmi-gazdasági helyzetéből, és nem a pedagógusok felkészültségéből adódnak, megerősíti, hogy a különféle platformok, szoftverek ismeretében nem volt szignifikáns eltérés a jobb, illetve a hátrányosabb helyzetű intézményekben dolgozó pedagógusok között, egyetlen alkalmazás, az OkosDoboz kivételével, amit viszont pont a hátrányos helyzetü iskolák tanárai ismertek nagyobb arányban.

Harmadik hipotézisünk úgy szólt, hogy a kifejezetten jó helyzetű diákokat oktató pedagógusok, köszönhetően a jobb felszereltségnek és a diákok fejlettebb digitális írástudásának, inkább tudtak valóban digitális oktatást megvalósítani. Ez a hipotézis részben igazolódott. Papíralapú dolgozatokat csak az ilyen iskolákban tanító pedagógusok 14,2 százaléka használt értékelésre, az órarendtől 57,2 százalékuk szabadon eltérhetett, a „digitális munkáltató” faktorban pedig felülreprezentáltak a jó és kifejezetten jó helyzetủ intézmények tanárai. Ugyanakkor a kifejezetten jó helyzetűeket tanítók felülreprezentáltak a „hagyományos oktató” faktorban is: ők az IKT-eszközök és szoftverek segítségével az iskolai környezetet igyekeztek modellezni, azaz online órákat tartottak és online feleltettek. 
A negyedik hipotézisünk az volt, hogy aki a digitális munkarend ideje alatt végül megismert megfelelő tanulástámogató alkalmazásokat, az ezeket a hagyományos oktatásba is nagyobb mértékben tervezi beilleszteni. Ez a hipotézis igazolódott: a digitális munkarend nagy nyertese a Google Classroom, amit a válaszadók több mint 40 százaléka megismert és megkedvelt. Emellett jól szerepelt a Redmenta, de említették a Wordwallt, a Moodle-t és mozaBookot is. Az elméleti áttekintésben idéztük Balázs (2020) kutatását, ami épp egy Google Classroommal támogatott oktatási folyamatot vizsgált, és eredményei szerint a diákok mind a motiváció, mint a tananyag elérhetősége szempontjából jobbnak értékelték ezt a formát a kizárólag hagyományos oktatásánál. Így, ha ezt valóban továbbviszi a pedagógusok egy része, az előrelépés lehet az oktatás minőségét tekintve. Azt azonban fontos szem előtt tartanunk, hogy a legtöbben (170 említés, ami a válaszadók több mint háromnegyede) a Facebookot, az e-mailt és a Messengert használták a digitális munkarend ideje alatt, és többnyire a hagyományos oktatást igyekeztek IKT-eszközök segítségével megvalósítani. Az írásos magyarázat és a PowerPoint dia volt az ismeretátadás leggyakrabban használt eszköze, az értékelésben pedig a pedagógus által javítandó feladat. A hagyományos formát erősítette az is, hogy a pedagógusok 44,6 százalékának előírták, hogy az órarend szerint tartson órákat (igaz, ennek a csoportnak a fele igyekezett rugalmasabban, a digitális oktatás szemléletének inkább megfelelően tartani az órákat, miközben a válaszadók további 21,1 százaléka az órarend tekintetében, külön előírás nélkül is, a hagyományos oktatást próbálta modellezni).

Eredményeink összességében azt mutatják, hogy a pedagógusok az esetek többségében ragaszkodtak a hagyományos ismeretátadási és értékelés módszerekhez, de ezek mellett igyekeztek a digitális alkalmazásokat, oktatási platformokat is használni; 40 százalékuk szeretné a hagyományos oktatásban is megőrizni a Google Classroomot.

A digitális oktatás, ezen belül kiemelten az akadályozó tényezők szemszögéből vizsgálva a digitális munkarend tanulságait, a jövőben érdemes lenne átgondolni azt a keretrendszert, amelybe a digitális oktatásnak be kellene lépnie. A digitális munkarend alatti dupla, tripla adminisztrációt például több pedagógus a legnagyobb negatívumként említette: támogathatná a digitális oktatás bővülését, ha az az adminisztratív terhek csökkenését tudná inkább magával hozni. A válaszadók közel 20 százaléka említette, hogy meglátása szerint a tananyag ebben a formában nem alkalmas a digitális oktatásra, ami szintén érinti a keretrendszert is.

Emellett kiemelt feladat a hátrányos helyzetű intézmények, diákok helyzetének javítása, mivel ezekben az iskolában főként az eszközhiány volt a digitális oktatás akadálya. Az ezekben tanuló diákok a digitális írástudás terén hasonló hátrányban lehetnek, mint amit a szövegértés és a matematika kompetenciamérései mutatnak.

További kutatásokat igényelne annak az ellentmondásnak feloldása, hogy miközben a megkérdezett pedagógusok 78,1 százaléka kellően felkészültnek érezte magát a digitális oktatásra, felük-háromnegyedük nem ismerte a különféle oktatási alkalmazásokat, platformokat, és a digitális munkarend során is elsősorban a facebookos és e-mailes kapcsolattartást részesítette előnyben. A továbbképzések hiányával ez nem magyarázható: igaz, hogy a válaszadók egyharmada nem részesült IKT-továbbképzésben az elmúlt öt évben, a fennmaradó kétharmad azonban legalább egy, de 
akár több olyan képzésen is részt vett, amit hasznosnak is talált. Valószínűsíthető, hogy hiányoznak a Sung, Kuo-En és Tzu-Chien (2016) által említett specifikus továbbképzések, de az is lehet, hogy a tanultakat nem sikerült beilleszteni a mindennapi munkába; egy későbbi kutatásnak a digitális pedagógiához kapcsolódó szemlélet és specifikus tudás meglétét és hiányait is célszerű lenne vizsgálnia.

\section{Irodalom}

Adesope, Olusola O. and Anthony G. Rud. „Maximizing the Affordances of Contemporary Technologies in Education: Promises and Possibilities.” In Adesope, Olusola O. and Anthony G. Rud (szerkesztők). Contemporary Technologies in Education, 1-15. London: Palgrave Macmillan, 2019.

Balázs Brigitta. „New methodological possibilities in digital training.” Journal of Applied Technical and Educational Science 10, no. 1 (2020):133-154.

https://doi.org/10.24368/jates.v10i1.163

Bourgeois, Ania, Peter Birch and Olga Davidovskaia. Digital Education at School in Europe. Luxembourg: Publications Office of the European Union, 2019.

Buda András. IKT és oktatás. Együtt vagy egymás mellett? Szeged: Belvedere Meridionale, 2017. Dicheva, Darina, Christo Dichev, Gennady Agre and Galia Angelova. „Gamification in Education: A Systematic Mapping Study.” Educational Technology \& Society 18, no.3.(2015): 1-14.

Hermann Zoltán, Imre Anna, Kádárné Fülöp Judit, Nagy Mária, Sági Matild és Varga Júlia. Pedagógusok az oktatás kulcsszereplői. Összefoglaló jelentés az OECD nemzetközi tanárkutatás (TALIS) első eredményeiről. Budapest: Oktatáskutató és Fejlesztő Intézet, 2009.

Hua, Shuyang and Zhongwei Ren. „'Online + Offline’ Course Teaching Based on Case Teaching Method: A Case Study of Entrepreneurship Education Course.” International Journal of Emerging Technologies in Learning 15, no. 10 (2020):69-85. https://doi.org/10.3991/ijet.v15i10.13999

Kadocsa László. Az atipikus oktatási módszerek. Kutatási zárótanulmány. Budapest: Nemzeti Felnőttképzési Intézet, 2006. https://mek.oszk.hu/06600/06655/06655.pdf

Kárpáti Andrea. „Az informatikai kompetenciától a digitális pedagógiáig, a nemzetközi kutatások tükrében.” In Dringó-Horváth Ida és N. Császi Ildikó (szerkesztők). Digitális tananyagok: Oktatásinformatikai kompetencia a tanárképzésben, 15-32. old. Budapest: L ,Harmattan Kiadó, 2013.

Kertesi Gábor és Kézdi Gábor. A roma és nem roma tanulók teszteredménye közti különbségekről és e különbségek okairól. Budapest: Magyar Tudományos Akadémia Közgazdaság- és Regionális Tudományi Kutatóközpont, 2012.

Kővári Attila. „A felnőttoktatás 4.0 és az ipar 4.0 kihívásai az életen át tartó tanulásban.” PedActa 9. évf, 1. szám (2019):9-16. 
Molnár Gyöngyvér és Pásztor-Kovács Anita. „A számítógépes vizsgáztatás infrastrukturális kérdései: az iskolák eszközparkjának helyzete és a változás tendenciái.” Iskolakultúra 25. évf., 4. szám (2015):49-61. http://dx.doi.org/10.17543/ISKKULT.2015.4.49

Molnár Gyöngyvér, Turcsányi-Szabó Márta és Kárpáti Andrea. „Digitális forradalom az oktatásban - perspektívák és dilemmák.” Magyar Tudomány 181. évf., 1. szám (2020):56-67. http://dx.doi.org/10.1556/2065.181.2020.1.6

Nelson, Klara, Marcy Courier and Gilbert W. Joseph. „An Investigation of Digital Literacy Needs of Students.” Journal of Information Systems Education 22, no. 2 (2011)95-109.

OECD. Students, Computers and Learning: Making the Connection. OECD Publishing, 2015. http:// www.oecd.org/publications/students-computers-and-learning-9789264239555-en.htm

OECD. TALIS 2018 Results. Teachers and School Leaders as Lifelong Learners. 2019. http://www.oecd.org/education/talis/

Sung, Yao-Ting, Kuo-En Chang and Tzu-Chien Liu. „The effects of integrating mobile devices with teaching and learning on students' learning performance: A meta-analysis and research synthesis.” Computers \& Education 94, (2016):252-275.

https://doi.org/10.1016/j.compedu.2015.11.008

Underwood, Jean. The impact of a digital technology: A review of the evidence of the impact of digital technologies on formal education. Coventry: Becta, 2009.

http://irep.ntu.ac.uk/id/eprint/5040 